DOI 10.15393/j10.art.2016.2721

Александр Владимирович Отливанчик

(Минск, Республика Беларусь)

AlexOt@yandex.ru

\title{
ДОСТОЕВСКИЙ - СОАВТОР А. У. ПОРЕЦКОГО и В. Ф. ПУЦЫКОВИЧА в «ГРАЖДАНИНЕ»: опыт атрибуцин*
}

Аннотация. Статья посвящена проблеме атрибуции публикаций еженедельника «Гражданин»: представлены доводы в пользу авторского участия Достоевского в статье «Семейная неурядица как причина самоубийства» («Гражданин». 1873. № 49; совместно с А. У. Порецким) и в обозрении «Иностранные события» («Гражданин». 1874. № 12; совместно с В. Ф. Пуцыковичем).

Ключевые слова: Ф. М. Достоевский, А. У. Порецкий, В. Ф. Пуцыкович, еженедельник «Гражданин», атрибуция, редактирование, соавторство

3

атронутая В. А. Викторовичем в № 4 «Неизвестного Достоевского» за прошлый год [6] сложная и многоаспектная тема редакторской работы Достоевского с авторскими текстами в «Гражданине» имеет достаточно обширную литературу [1]; [2]; [3]; [4]; [7]; [8]; [16]; [17]; [19]. Достоевский был «въедливым» редактором и, по свидетельству метранпажа «Гражданина» М. А. Александрова, «немногое подписывал с одной корректуры»1). Интенсивность творческого труда Достоевского - литературного редактора - вполне подтверждается деловой и личной перепиской романиста в 1873 году; эти эпистолярные свидетельства неоднократно цитировались исследователями $[6,12] ;[17,71]$. Деятельность Достоевского как литературного редактора в «Гражданине» была многогранной: это и перекомпоновка авторских текстов, и написание предисловных (послесловных) заметок к публикациям, и снабжение материалов сносками-примечаниями, ремарками «технического» (отсылочного) характера, и написание текстовых вставок, и правка авторских заголовков, и т. п. Редакторскому вмешательству Достоевского подвергались публицистические тексты и художественные произведения: как прозаические, так и стихотворные [3], и даже драматические [1]. Аналогично, на тех же принципах, Достоевский вел редакторскую работу еще в 1860-е годы в процессе издания журналов «Время» и «Эпоха» [9]; [10]; [11, 12]; [13]; [15]; [19]; [20].

В этой связи особым феноменом было соавторское творчество Достоевского-журналиста: как правило, оно «вырастало» из активной редакторской правки представленных в журнал рукописей. Документальные источники и результаты текстологических исследований позволяют говорить о двойном авторстве (В. П. Мещерскиц̆, Ф. М. Достоевский) «Петербургского обозрения» в №№ 10 и 45 «Гражданина» 1873 года [4, 168-171]; 
$[5,17]$, статьи «Свежей памяти Ф. И. Тютчева» [2]; [4, 165-168], а по нашему мнению, и «Ответа на протест» $[17,73-76]$. Совместно с Т. И. Филипповым Достоевским написана заметка «От редакции» в № 181873 года [14, 370-371]; не без участия Филиппова же (представившего тезисный план будущей публикации ${ }^{2)}$ ) Достоевский составил журналистский отчет «Заседание Общества любителей духовного просвещения 28 марта».

Есть основания говорить о подобном же совместном творчестве Достоевского с постоянным обозревателем «Гражданина» А. У. Порецким и секретарем редакции (с 1874 года - редактором) журнала В. Ф. Пуцыковичем. Вниманию читателей предлагаются два текста из «Гражданина»: статья «Семейная неурядица как причина самоубийства» (1873. № 49) и обозрение «Иностранные события» (1874. № 12). Доводы в пользу причастности Достоевского к написанию этих текстов впервые были представлены нами в виде докладов на Международных Старорусских чтениях «Достоевский и современность», соответственно, в 2006 и 2008 годах [16]; [18]. В данной работе уточняется и расширяется доказательная база атрибуции обеих публикаций.

1

<Ф. М. Достоевский, А. У. Порецкий>

\section{СЕМЕЙНАЯ НЕУРЯДИЦА КАКЪ ПРИЧИНА САМОУБІЙСТВА}

\section{(Гражданинъ. 1873. 3 Декабря. № 49. С. 1315-1317)}

Мы сегодня прочитали въ одной изъ крупныхъ петербургскихъ газетъ нижесльдующее. Просимъ читателей обратить вниманіе на эти строки. Они доказываютъ какъ черезъ-чуръ уже легкомысленно обращается наша псевдо-либеральная пресса съ главными основами нашей семейной жизни.

«Печальная исторія самоубійства двухъ охтянокъ въ настоящее время, какъ слышало "Новое Время", разъяснена на столько, что можно

\footnotetext{
${ }^{1}$ Цитируемая заметка первоначально была помещена в газете «Новое Время» 27 ноября 1873 года (с. 3). Вскоре ее перепечатали две крупные петербургские газеты - «С.-Петербургские Ведомости» (1873. 28 нояб<ря> (10 дек<абря>). С. 2) и «Биржевые Ведомости» (1873. 29 нояб<ря> (11 дек<абря>). С. 3) - и две менее влиятельные - «Петербургская Газета» (1873.29 нояб<ря>. С. 2) и «Петербургский Листок» (1873. 2 (14) дек<абря>. С. 1). Установить непосредственный источник «Гражданина» позволяют особенности оформления текста в названных газетах и вариантность норм русского правописания и синтаксиса XIX века, проявившаяся при перепечатке заметки разными изданиями. Так, в «Петербургском Листке» тексту дан редакционный заголовок «Разъясненіе», название газеты «Новое Время» сокращено до аббревиатуры «Н. В.». В «Биржевых Ведомостях» имеются следующие отличия от публикации «Гражданина»: съ жизнію вместо съ жизнью; раздельное написание частицы то
} 
безошибочно опредълить причину ихъ рЂшимости разстаться съ жизнью. Семейство, въ которомъ жили несчастныя, представляетъ образецъ неурядицы. Отецъ ихъ - типъ довольно не рбдкій въ русскомъ обществъ, съ характеромъ суровымъ, деспотическимъ и самолюбивымъ. Вся идея воспитанія дътей, по его понятію, должна заключаться въ безусловномъ повиновеніи родительской власти; а предпочтеніе сыновей дочерямъ, основанное на мнимой безполезности для семейства послъднихъ, въ его глазахъ совершенно естественно, что видно изъ предсмертной записки, писанной рукою старшей сестры Александры. Вотъ безсвязное, но характерное содержаніе ея, такъ сказать, посльдняго слова: “Прибыль... ненависть... добровольная смерть... трудъ-трудъ... печаль, радость... Такъ-то дочерей-то своихъ... Ахъ!.. родители-родители!.. Любите мальчиковъ, а дъвочекъ нътъ... Здъсь все...”. Подъ этими словами нарисована могила, по бокамъ два восьмиугольныхъ креста, а на могиль надпись “вода!!”. Пониже еще надпись “Александра... Марія” - имена несчастныхъ. Эта записка и другія обстоятельства семейной обстановки и жизни погибшихъ дъвицъ ${ }^{1}$ содержатъ въ себъ цълую драму.»

Вникните, читатели, хорошенько въ духъ этихъ строкъ.

Печальная исторія самоубійства двухъ охтянокъ, говоритъ газета, разъяснена по словамъ другой газеты «Новаго Времени», на столько, что можно безочибочно опредплить причину ихъ ргошимости разстаться съ жизнью.

(«Такъ то дочерей то своихъ...»); в первой фразе обстоятельство въ настоящее время выделено запятыми; во фразе «на могиль надпись “вода!!”» после надпись двоеточие, второй восклицательный знак после вода отсутствует. В «Петербургской Газете» наречие настолько и вводное выражение такъ сказать пишутся через дефис (в остальных газетах и в «Гражданине» - раздельно); не рпдкій пишется слитно; имеется одно отличие в пунктуации. Приведенный «Гражданином» текст полностью совпадает с публикацией «С.-Петербургских Ведомостей». Нежелание автора «Семейной неурядицы...» непосредственно затрагивать в полемике «С.-Петербургские Ведомости» представляется неслучайным. Будучи редактором «Гражданина», Достоевский предпочитал не обострять отношений своего издания с этой газетой, о чем свидетельствует состоявшийся в конце октября - начале ноября 1873 года его обмен письмами с В. П. Мещерским. Речь шла о необоснованных нападках «С.-Петербургских Ведомостей» (номер от 31 октября) на «Гражданин» («...“Гражданинъ” не усомнился обращаться къ пособію администраціи для своего распространенія...»); Достоевский - к неудовольствию Мещерского («...непонимаю признаюсь Вашей деликатности къ подлой выходкь С<анкт>петерб<хргскихъ $>$ Впд <омостей>» РО ИРЛИ. Ф. 100. № 29777. Л. 30 об.) - предлагал обойтись с газетой «на первый случай, как можно мягче» (Д30, т. 29, кн. 1, с. 307).

1 Эти слова могут указывать на то, что данные обстоятельства были известны сотруднику «Нового Времени». 
Любопытство читателя возбуждено; онъ спрашиваетъ нетерпъливо: какія же это причины?

Причины сльдующія:

1) Суровый, деспотическій и самолюбивый характеръ отца.

2) Идея воспитанія, заключающаяся въ безусловномъ повиновеніи родительской власти, и

3) предпочтеніе однимъ изъ родителей сыновей дочерямъ.

Какія же доказательства тому что именно эти причины побудили двухъ дъвицъ утопиться? спрашиваеть читатель.

А доказательство въ томъ безсвязномъ, но характерномъ содержаніи предсмертной записки, найденной у этихъ несчастныхъ.

Чъмъ же оно характерно? спросить читатель.

А тьмъ что въ ней вотъ что написано: «прибыль... ненависть... добровольная смерть... трудъ-трудъ... печаль, радость... Такъ-то дочерей-то свочхъ... Ахъ! родители-родители!.. Любите мальчиковъ, а дювочекъ

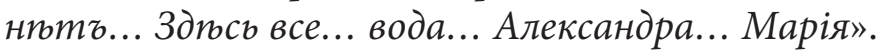

Но, скажетъ читатель, не можетъ же быть чтобы газеты находили все это причинами къ самоубійству понятными; въроятно онъ отъ себя прибавили нъсколько словъ строгаго осужденія, или хотя бы нъсколько размышленій доказывающихъ что онъ не одобряютъ такое самоубійство...

Какая наивность! скажемъ мы читателю: ни единаго слова не прибавили въ осужденіе этого безумнаго поступка двухъ дъвицъ, напротивъ!

Какъ напротивъ? прерываетъ насъ читатель. Неужели же газеты, про которыя вы говорите, сочувственно отзываются объ этомъ самоубійствъ? не можетъ это быть!

Сочувственно не сочувственно, но вникните въ смыслъ этой газетной фразы: «Семейство, въ которомъ жили несчастныя, представляеть образеиъ неурядицьљ».

Это уже слова выражающія воззрьнія газеты на семейную жизнь.

Что такое, по ея мнънію, образецъ неурядицы въ семействъ? спрашиваетъ читатель, прочитавши подчеркнутую нами фразу.

Газета отвьчаетъ: образеиъ неурядиць въ семействп есть присутствіе въ немг суроваго, деспотическаго и самолюбиваго отия, требуюшаго безусловнаго повиновенія родительской власти оть дютей и признаюшаго естественнымь проявлять въ отношеніяхъ родителей къ дптямб предпочтеніе сыновей дочерямъ.

Теперь представьте себъ дъвушку читающую эти строки въ газеть, и наивно сльпо върящую что эта газета есть органъ общественнаго мнънія: какое произведутъ на нее эти строки вліяніе, буде она не тверда ни въ религіи, ни въ пониманіи нравственныхъ и семейныхъ началь? (а такихъ дъвушекъ теперь совсъмъ не мало). 
Не скажетъ ли она себъ: во первыхъ я имъю право судить моего отца; если по моему суду окажется что онъ суровъ, деспотиченъ, самолюбивъ, если онъ требуетъ отъ дътей безусловнаго подчиненія родительской власти, если онъ сыновей предпочитаетъ дочерямъ, тогда онъ выходитъ образцомъ семейной неурядицы; а если это образецъ неурядицы, то я могу и не слушать его, я могу протестовать противъ насилія, я могу жаловаться обществу, газетамъ, мировому судь $\mathfrak{b}^{1}$. Сумбуръ вошелъ въ голову дъвушки: фальшь есть, а затъмъ, при первомъ удобномъ случаъ, является попытка дъвушки открыто неповиноваться отцу или матери, потомъ требованіе родителями повиновенія, потомъ противодъйствіе имъ уже съ озлобленіемъ, затъмъ постепенное установленіе отношеній натянутыхъ, проникнутыхъ взаимнымъ недовъріемъ, потомъ полное обособленіе дъвушки отъ міра ея родителей, и такъ далъе, до той минуты пока какое нибудь чрезвычайное событіе, напримъръ любовь къ кому нибудь дъвушки, или какая нибудь смълая рбшимость избрать себъ, вопреки воль родителей, самостоятельную карьеру, не поставятъ дъвушку передъ родителями въ окончательную съ ними рознь. И мудрено-ли что въ такую минуту, дъвушка, задавшись фальшивою мыслью что она судья своихъ родителей, что родители ея деспоты, что жизнь ея въ эту минуту ломаетъ будто-бы этоть деспотизмъ, что общество и печать стоятъ за нее и противъ родителей, все болъе и болъе приходитъ въ экзальтированное состояніе, и не видя въ этой схваткъ экзальтаціи съ дъйствительностью никакого исхода, пишетъ записку безсвязную, въ родъ той которую мы прочитали выше, пишетъ для общества, для печати, пишетъ съ мыслію что она мученица, и затьмъ кидается въ воду, говоря себъ: я умру, но записка моя меня переживетъ!

Все это въ нашъ въкъ всеобщаго сумбура въ мысляхъ и чувствахъ весьма возможно и даже при всей своей противоестественности можетъ казаться естественнымъ.

Но вотъ что неестественно: это легкомысліе печати.

Самоубійство дъвушки живущей въ семьъ само по себъ фактъ столь важный, когда ръчь идетъ объ оглашеніи его въ печати, что психическій его анализъ набрасываетъ на́-скоро, на основаніи пустыхъ догадокъ и слуховъ и безсвязной и безсмысленной записки, съ тъмъ чтобы такія легкомысленныя сужденія признавать безошибочнымъ разъясненіемъ причинъ самоубійства двухъ дъвушекъ - болъе чъмъ странно; ибо всякій знаетъ какое, къ сожалънію, огромное вліяніе на умы молодежи имъетъ

${ }^{1}$ Придание внутрисемейным конфликтам публичного характера, решение их путем судебных разбирательств Достоевский считал ненормальной практикой, допустимой лишь в исключительных случаях. Ср. статью «Дело родителей Джунковских с родными детьми»: «Просто им неловко было судиться с отцом $<\ldots>$ тогда как он, не думая о будущем и о том, какие чувства останутся в сердце этих детей от этого дня <...> жалуется суду, публике, обществу» (Д30, т. 25, с. 186). 
у насъ та печать, которая, какъ газетная, страдаетъ болъе всего недугомъ необдуманности, поверхностности и легкомыслія.

Не говоря уже о томъ что всъ сообщаемыя положительныя догадки газетою «Новымъ Временемъ» совершенно, однакоже, ничъмъ не доказаны; - не говоря объ этомъ, обратимся къ самимъ фактамъ, будто бы разъясняющимъ самоубійство для редакціи газеты «Новое Время».

По понятіямъ о семейной жизни, внесеннымъ въ міръ христіанствомъ, въ которыхъ мы всъ воспитывались, дютямғ судить родителей не приходится даже и тогда, когда родители проявляютъ какіе либо крупные недостатки. Случаи есть когда исполнить это трудно, но несомнънно что сльдуетъ сдерживать себя сердечно. На родителяхъ въ этомъ же смысль лежатъ тоже не менъе важныя обязанности, но забвеніе ихъ одною стороною отнюдь не освобождаетъ отъ нихъ другую. Что же сказать о такихъ недостаткахъ, какъ самолюбіе, суровость и даже деспотичность родителей?

Вдумался ли тотъ кто писалъ эти оправдательныя строки въ пользу несчастныхъ утопленницъ Охты въ смыслъ имъ высказанныхъ обвиненій противъ родителей, когда называлъ эти нравственныя черты родителей образцомъ семейной неурядицы? Вьроятно не вдумался, ибо иначе его прежде всего поразила бы мысль что всь эти прилагательныя: «суровый, деспотичный, самолюбивый», въ примъненіи къ свойствамъ родителей, тогда только могутъ получить силу тяжкаго обвиненія родителей относительно дътей, когда они доказываются рядомъ возмутительныхъ поступковъ этими родителями противъ дътей совершенныхъ. Но когда, какъ въ настоящемъ случаъ, называются однъ только черты личности родителей, а фактовъ въскихъ въ доказательство уродливости этихъ чертъ не приводится, тогда газета принимаетъ на себя тяжелую отвътственность передъ обществомъ за то что даетъ всякому ребенку право называть самолюбіемъ, суровостью и деспотизмомъ въ родителяхъ своихъ все что ему захочется и все что ему вздумается!

Отецъ вырветъ изъ рукъ дочери атеистическую книгу - это деспотизмъ, скажетъ дочь; отецъ не позволить дочери знакомиться съ какимъ нибудь студентомъ медицинской академіи, - это суровость и деспотизмъ; отецъ запретитъ дочери выходить одной на улицу, - это деспотизмъ; отецъ станетъ усовЂщевать дочь за ръзкія ея выходки, - это суровость. И такъ до безконечности! Пусть это выражается иногда со стороны родителей дъйствительно строго, съ излишнею и угрюмою мнительностью, съ раздражительностью и взыскательностью, но деспотизмъ-ли это въ самомъ дъль и достаточная ли это причина къ самоубійству? Что же касается до самолюбія, какъ недостатка въ родителяхъ объясняющаго безошибочно нравственную причину самоубійства дочери, - то, признаемся, тутъ уже просто газета поставила слово въроятно сама не зная зачъмъ, ибо понятія о самолюбіи отца или матери, какъ о признакъ семейной неурядицы, понять никто не можеть. 
Но еще непонятнъе чтобы можно было признавать предсмертную записку, написанную этими несчастными дъвицами въ томъ видъ, въ какомъ она была будто бы найдена, - документомъ, на основаніи котораго можно было бы дълать не только заключенія, но даже мало-мальски въроятныя догадки; ибо всякій со свъжаго воздуха здравомыслящій человъкъ пойметъ что такая безсвязная записка - есть ничто иное какъ проявленіе или какого-то бреда, или какого нибудь болъзненнаго умысла: о болъзни и говорить бы какъ о болъзни; а между тъмъ газета строитъ на этой запискъ цълое зданіе обвиненія родителей въ какомъ-то странномъ предпочитаніи сыновей дочерямъ, и въ деспотизмъ.

Наконецъ, спрашиваемъ мы, какое право имъетъ газета, съ такимъ болъе чъмъ плохимъ запасомъ точныхъ обвиненій, вторгаться въ семейную жизнь честной семьи, и съ цълью оправдывать ненуждающихся уже въ земномъ оправданіи двухъ бъдныхъ дъвицъ, погибшихъ жертвами непониманія своего христіанскаго долга, набрасывать тънь тяжкихъ и голословныхъ обвиненій въ суровости, деспотизмъ и тому подобныхъ свойствахъ на остающихся въ живыхъ, и безъ того уже пораженныхъ горемъ родителей?

Или эти газеты не знаютъ что семейная жизнь есть святыня, до которой печать не смъетъ дотрогиваться до тъхъ поръ, пока въ этой семьъ не совершено преступленіе противъ общества? Какое же преступленіе совершили несчастные родители этихъ утопленицъ?

И неужели всякій разъ какъ въ какой-либо семьъ будутъ убивать себя сбитые съ толку жизненною фальшью нашего времени и нашего общества, газеты будутъ присвоивать себъ право нравственныхъ сльдователей, и вторгаться въ семейную жизнь, чтобы обвинять однихъ и оправдывать во что бы то ни стало другихъ?

А отъ этого мы очень недалеки, ибо не забудемъ что по поводу этого событія, газета назвала требованіе родителями отъ дътей безусловнаго подчиненія ихъ власти, то есть то начало, которое христіанство положило въ основу семейной жизни, безошибочно понятною причиною самоубійства!

И такъ всякій разъ что родители, даже съ полною любовью и безъ всякаго «деспотизма», будутъ требовать отъ дътей то что они должны требовать, какъ родители, - т. е. полнаго подчнненія ихъ власти, а дъти всльдствіе этого будутъ стрьляться и топиться, то родители будутъ предаваемы печатью на позоръ, а дъти будутъ возводимы въ санъ мучениковъ?

Пріятная будущность для нашей семейной жизни впереди! 


\section{КОММЕНТАРИЙ}

Лексико-стилистические особенности публикации, в частности, использование авторского $\mathcal{M b l ~ ( « М ы ~ с е г о д н я ~ п р о ч и т а л и » , ~ « п р о с и м ъ ~ ч и т а т е л е и ̆ » , ~ « с к а ж е м ъ ~ м ы ~}$ читателю» и др.) однозначно указывают на редакционный характер этой статьи. Это исключает авторство временного сотрудника или случайного корреспондента «Гражданина».

В период редакторства Достоевского авторская подпись П. встречается на страницах газеты-журнала трижды. Кроме комментируемой публикации, криптонимом П. помечены статьи «Неоцененное побуждение» в № 451873 года $^{3)}$ и «Психологический вопрос из дела Непениных (Письмо к редактору)» в № 101874 года. Текстологический анализ обеих статей и документальный источник (письмо А. У. Порецкого к Ф. М. Достоевскому от 31 октября 1873 года - РО ИРЛИ. Ф. 100. № 29821) свидетельствуют о принадлежности этих публикаций А. У. Порецкому. По-видимому, его же следует считать автором первоначального варианта статьи «Семейная неурядица как причина самоубийства» ${ }^{4}$.

Есть основания думать, что статья А. У. Порецкого «Семейная неурядица...» была существенным образом переработана («переписана») редактором «Гражданина» ${ }^{5}$. Основные доводы в пользу активного вмешательства редактора в авторский текст:

1. Заметное несоответствие стиля статьи - нервно-эмоционального, энергичного, с нажимом - обычной стилистике публикаций А. У. Порецкого

2. Несочетаемость ряда содержащихся в статье суждений (трактовка проблемы суицида, понимание пределов родительской власти над совершеннолетними детьми) с мировоззренческими установками А. У. Порецкого, отразившимися, в частности, в его статье-обозрении «Из текущей жизни» в том же номере «Гражданина». В «противовес» намеренно строгому осуждению девушек-самоубийц в «Семейной неурядице...» (погибли «жертвами непониманія своего христіанскаго долга») Порецкий с состраданием, без порицания рассказывает о попытке самоубийства молодой крестьянки из Кологривского уезда ${ }^{7}$. Одной из причин трагической ситуации была воля родителей жениха героини («ласками, настойчивостью, угрозами - заставили его жениться на <..> другой»). Явно не подкрепляет доводы статьи «Семейная неурядица...» в пользу «полнаго», «безусловнаго» подчинения взрослых детей власти родителей обрисованная в другом сюжете обозрения Порецкого личность отца, сожительствовавшего с дочерью (тесть Ивана Варварина $)^{8)}$. Эффект несочетаемости двух материалов журнального номеpa, написанных примерно в одно и то же время, усиливает то, что в журнале они помещены рядом, один за другим.

3. Использование в графическом оформлении текста жирного шрифта, отсуmствующего в публикациях А. У. Порецкого в «Гражданине». Более сильное в сравнении с курсивом средство акцентирования, жирный шрифт применялся в материалах «Гражданина» довольно редко. Кроме статьи «Семейная неурядица...», мы находим его всего в 23 статьях и заметках, опубликованных в редакторство 
Достоевского ${ }^{9)}$ (писателем выпущено 65 номеров издания, в т. ч. два сдвоенных). Анализ данных текстов дает право считать применение в публикации жирного шрифта веским указанием на участие в ее подготовке либо В. П. Мещерского, либо Ф. М. Достоевского ${ }^{10)}$. Однако В. П. Мещерский в 1873 - начале 1874 года практически не занимался в «Гражданине» литературной правкой рукописей.

Проблема «участившихся самоубийств» («самоубийства у нас до того в последнее время усилились, что никто уж и не говорит об них. Русская земля как будто потеряла силу держать на себе людей» (Д30, т. 23, с. 24)) привлекала внимание Достоевского-публициста еще в «гражданинский» период («Среда», «Две заметки редактора», замысел статьи о Елизавете Гейденрейх). Позднее - в «Дневнике Писателя» 1876-1877 годов - проблема получит детальную разработку средствами публицистического анализа («Одна несоответственная идея», «Два самоубийства», «Приговор», «Запоздавшее нравоучение», «О самоубийстве и о высокомерии», «Именинник» и др.) и художественного осмысления («Кроткая», «Сон смешного человека»). Достоевский укажет и подчеркнет (1876): «Мы <...> видим очень много $<\ldots>$ самоубийств, странных и загадочных, сделанных вовсе не по нужде, не по обиде, без всяких видимых к тому причин, вовсе не вследствие материальных недостатков <... Такие случаи в наш век составляют большой соблазн». Он даст следующее объяснение отмеченному феномену: «...в большинстве <...> прямо или косвенно, эти самоубийцы покончили с собой из-за одной и той же духовной болезни - от отсутствия высшей идеи существования в душе их» (Д30, т. 24, с. 50). Такие самоубийства Достоевский противопоставляет самоубийствам, совершенным от безысходности, - подобным тем, что описаны им в статьях «Среда» (случай крестьянки Аграфены Саяпиной), «Два самоубийства» (случай швеи Марьи Борисовой). Осуждение самоубийства, сделанного человеком «от отсутствия высших целей жизни», обычно не отменяет у Достоевского сострадания к умершему: «...к этим фактам надо относиться человеколюбивее $<\ldots>$ В фактах этих, может быть, мы и сами все виноваты» (Д30, т. 24, с. 54). Однако в отдельных случаях самоубийцы удостаиваются весьма жестких (без оттенка жалости) оценок в записных тетрадях писателя: «Читал письмо о барышне, кончив<шей> самоубийством. Нет высшего сознания жизни, то есть сознания долга и правды, что единственно составляет счастье. И как она устала, о как она устала, какое матерьяльное понимание в счастье, распределение денег <...> Как противно» (о самоубийстве Надежды Писаревой) (Д30, т. 24, с. 211).

В записной тетради «гражданинского» периода встречаем сходную по смыслу отметку о самоубийстве Елизаветы Гейденрейх (последняя треть сентября 1873 года - за два месяца до появления в «Гражданине» статьи «Семейная неурядица...»): «Жаль, но негодование, отвращение <...>

Нет, настоящего живого чувства тут не было, тут была книжка в голове (если она образованная барышня).

Своенравие и современная идея, что всё мне принадлежит, а я никому и ничего не должна. 
Застрелиться под музыку» (Д30, т. 21, с. 254).

Невеста купца-миллионера Е. Гейденрейх покончила с собой на подмосковной даче на балу после того, как была оскорблена женихом. Примечательно, что к жениху-обидчику Достоевский оказывается более снисходителен: «...имел же, кроме питья, достоинства <..> Он безобразник, но это безобразие <..> даже не ужаснее битья зеркал и тарелок» (Там же). У писателя возникает замысел статьи о невесте-самоубийце. 25 сентября 1873 года Вс. С. Соловьев сообщает в Москву своей матери, П. В. Соловьевой, что Достоевский «хочет <...> написать статью», и от имени писателя обращается к ней «с просьбою ответить на следующие вопросы: 1) что говорят в Москве - симпатизируют ли девушке и порицают купчика-богача, или наоборот, со стороны его не видят особенной вины, а ее резоны находят несерьезными? 2) была ли она объявленной невестой? <..> 4) не известны ли фамилии и место действия» [14, 417]. Однако, не дожидаясь сведений от П. В. Соловьевой (во всяком случае, в дневниковой отметке писателя эти сведения, в т. ч. даже фамилии, не зафиксированы), Достоевский заносит в записную тетрадь готовое суждение ${ }^{11)}$. Таким образом, в сентябрьском замысле писателя-публициста очевидна изначальная установка осудить самоубийцу прежде подробного выяснения обстоятельств. Подобная установка впоследствии будет реализована в журнале Достоевского в статье «Семейная неурядица...». Так, при наличии записки погибших дочерей с обвинением, однозначно направленным против родителей, автор статьи характеризует затронутое трагедией семейство как «честную семью» и возлагает всю тяжесть вины за случившееся на дочерей-самоубийц.

Весьма существенно в записи Достоевского об истории Е. Гейденрейх двойное упоминание о расчете самоубийць на публичность: «Надо было газет и публики», «Ей надо было публики и газет» (Д30, т. 21, с. 254, 256). Та же мысль, выраженная сходным образом, присутствует в статье «Семейная неурядица...»: «пишетъ записку <...> для общества, для печати <..> и затьмъ кидается въ воду» (в том же абзаце статьи выше находим еще два упоминания об «обществе и газетах»: «я могу жаловаться обществу, газетамъ», «фальшивою мыслью <..> что общество и печать стоятъ за нее»). Такое «совпадение» очевидно свидетельствует об участии Достоевского в подготовке текста статьи.

Кроме этого, можно провести разноплановые аналогии между «Семейной неурядицей...» и публицистическими текстами Достоевского, главным образом, «гражданинского» периода (наибольшее количество соответствий обнаруживается в статье «Одна из современных фальшей», опубликованной в следующем, 50-м, номере «Гражданина» 1873 года):

a) Композиционные приемь. Статьи «Семейная неурядица...» и «Одна из современных фальшей» начинаются с внешне малозначимой газетной цитаты; затем автор указывает реальный масштаб скрытого за цитатой неблагоприятного 
(потенциально опасного) общественного явления. Далее разворачивается настойчивая, несколько «придирчивая» полемика, в ходе которой тема статьи получает окончательную разработку. В «Семейной неурядице...» используется и характерный публицистике Достоевского прием мысленного диалога ${ }^{12)}$ : «Любопытство читателя возбуждено; онъ спрашиваетъ нетерпъливо: какія же это причины?

Причины сльдующія <..>

Какія же доказательства тому что именно эти причины побудили двухъ дъвицъ утопиться? спрашиваетъ читатель.

А доказательство въ томъ безсвязномъ, но характерномь содержаніи предсмертной записки <...>

Чъмъ же оно характерно? спроситъ читатель.

А тъмъ что въ ней вотъ что написано <...>

Но, скажетъ читатель, не можетъ же быть чтобы газеты находили все это причинами къ самоубійству понятными <...>

Какая наивность! скажемъ мы читателю», - и т. д.

б) Особенности построения фраз, синтаксис статьи. Обращает на себя внимание следующая параллель с текстом обозрения Достоевского «Иностранные события» в № 51 «Гражданина» 1873 года. Желчно-иронический комментарий в двух совершенно разных случаях выражен сходным оборотом фразы: «Все это въ нашъ въкъ всеобщаго сумбура въ мысляхъ и чувствахъ весьма возможно и даже при всей своей противоестественности можетъ казаться естественнымъ» - «Весьма может быть, что все эти чудеса в Испании и есть нормальное ее состояние» (Д30, т. 21, с. 238). В «Семейной неурядице...» многократно встречаются свойственные стилю Достоевского синтаксические инверсии: «случаи есть», «сдерживать себя сердечно», «тогда только», «фактовъ въскихъ» и др.

в) Образные понятия. Сестры-самоубийцы признаются мнимыми мученицзами: «...не видя въ этой схваткъ экзальтаціи съ дъйствительностью никакого исхода, пишетъ записку безсвязную <...> пишетъ съ мыслію что она мученица»; «...родители будутъ предаваемы печатью на позоръ, а дъти будутъ возводимы въ санъ мучениковъ?» - ср. пассаж о петрашевцах в «Одной из современных фальшей»: «...то дело, за которое нас осудили, те мысли, те понятия, которые владели нашим духом, представлялись нам не только не требующими раскаяния, но даже <..>> мученичеством, за которое многое нам простится!» (Д30, т. 21, с. 133) (расценивалось «поздним» Достоевским как заблуждение). В безусловной связи с образной системой Достоевского находится употребленное в комментируемой статье выражение «всякій со свЂжаго воздуха здравомыслящій человъкъ» ср.: «Бывают такие времена в жизни народа, что в нем особенно чувствуется потребность выйти на свежий воздух <..> в ближайшее время к Петру уже чувствовал народ худобу жизни, заявлял свой протест против действительности и пытался выйти на свежий воздух...» («Два лагеря теоретиков (по поводу “Дня” 
и кой-чего другого)» (Д30, т. 20, с. 14)); «...просто стало душно жить, вроде того, как бы воздуху недостало» («Два самоубийства» (Д30, т. 23, с. 146)).

г) Лексика. Из «узнаваемых» слов и выражений Достоевского в статье встречаем:

сумбуръ: «Сумбуръ вошелъ въ голову дъвушки»; «нашъ въкъ всеобщаго сумбура въ мысляхъ и чувствахъ» - ср.: «Что за сумбур? Кто может поверить такому обвинению?»; «Двадцать лет назад известие о каких-то бегущих в Америку гимназистах из 3-го класса гимназии показалось бы мне сумбуром» («Одна из современных фальшей» (Д30, т. 21, с. 127, 135));

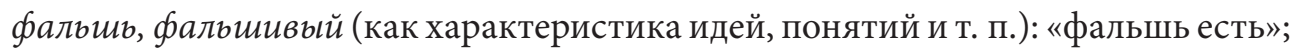
«задавшись фальшивою мыслью что она судья своихъ родителей»; «сбитые съ толку жизненною фальшью нашего времени и нашего общества» - ср.: «И вообще во всем этом волнении, которое называется теперь женским вопросом, несомненно слышится чрезвычайная фальшь» (предисловие к статье Л. Ю. Кохновой «Ответ женщины на призыв “Гражданина” “К делу!” (Д30, т. 21, с. 276)); «кругом нас такой туман фальшивых идей» («Одна из современных фальшей» (Д30, т. 21, c. 136));

во что бы <mo> ни стало: «обвинять однихъ и оправдывать во что бы то ни стало другихъ» - ср.: «Отрицанием факта во что бы ни стало можно достигнуть удивительных результатов» («Одна из современных фальшей» (Д30, т. 21, c. 128) $)^{13)}$; «...гениальная нация хочет жить <...> во что бы то ни стало» («Иностранные события» в № 51 «Гражданина» (Д30, т. 21, с. 237)); «...ее ошибки не таковы, чтобы православным <..> нужно было во что бы то ни стало отрицать их» («Разъяснение некоторых сторон вопроса о нуждах единоверия» $[5,29]$ );

псевдо-либеральныци: «наша псевдо-либеральная пресса» - ср.: «Вот уже с незапамятных псевдолиберальных наших времен»; «многим органам нашей псевдолиберальной прессы» («Одна из современных фальшей» (Д30, т. 21, с. 126, 127));

газетная печать: «та печать, которая, какъ газетная, страдаетъ болье всего недугомъ необдуманности» ${ }^{14)}$ - ср.: «в нашей газетной прессе» («Одна из современных фальшей» (Д30, т. 21, с. 126)).

Идейно-тематический и лексико-стилистический анализ статьи «Семейная неурядица...», таким образом, позволяет установить факт участия Достоевского в написании текста. В статье в измененном виде и на новой фактической основе «воплотился» недавний (сентябрьский) публицистический замысел Достоевского со «строгим осуждением» самоубийства. Статье «Семейная неурядица...» предшествовал материал на ту же тему А. У. Порецкого, не вполне удовлетворивший Достоевского как редактора и значительно переработанный им. 
<В. Ф. Пуцыкович, Ф. М. Достоевский>

\section{ИНОСТРАННЫЯ СОБЫТІЯ \\ (Гражданинъ. 1874. 25 Марта. № 12. С. 346-348)}

10 (22) марта, въ Берлинъ торжественно праздновали годовщину дня рожденія маститаго германскаго императора ${ }^{1}$. Отвъчая на поздравительную ръчь фельдмаршала Врангеля², императоръ коснулся внутренней германской политики. «Такъ какъ вы явились представителями арміи, между прочимъ, сказалъ императоръ, обращаясь къ Врангелю и всъмъ явившимся къ нему генераламъ, то я не могу умолчать насчетъ того, что, повидимому, надъ нею носится новый кризисъ». Затъмъ прибавилъ, что Германія всъмъ обязана союзной арміи и что сознаніе этого одобряетъ ${ }^{3}$ его быть настойчивымъ не для возбужденія войны, а для сохраненія мира въ Европъ... Въ этихъ словахъ императоръ-воинъ желалъ, безъ сомнънія, выразить собравшемуся передъ нимъ высшему воинству свое огорченіе, за нъсколько дней до того испытанное имъ, всльдствіе противодъйствія со стороны парламентской коммисіи рейхстага военному закону ${ }^{4}$, который недавно защищаль своею знаменитою рбчью фельдмаршаль Мольтке Но слова эти подняли немалую тревогу во всей Германіи. Теперь то и дъло въ печати толкуютъ о неизбъжномъ ръшительномъ столкновеніи правительства съ парламентомъ (и при томъ съ партіею націоналъ-либераловъ ${ }^{6}$ )

${ }^{1}$ Император Германии Вильгельм I Гогенцоллерн (Hohenzollern, 1797-1888) родился 22 марта (н. ст.) 1797 года.

${ }^{2}$ Врангель (Wrangel) Фридрих-Генрих-Эрнест (1784-1877) - прусский генерал-фельдмаршал (с 1856 года). Участвовал в войнах с наполеоновской Францией (1807 и 1813 годов), в немецко-датской войне 1848 года. Был возведен в графское достоинство в 1864 году.

${ }^{3}$ Опечатка. Должно быть: «ободряетъ».

${ }^{4}$ Коммисія рейхстага отвергла первый параграфъ военнаго закона, по которому, какъ мы уже сообщали, требуется постоянный контингентъ арміи въ мирное время въ 401,000 чел. (Примеч. В. Ф. Пуиыковича). В. Ф. Пуцыкович здесь ссылается на свое обозрение «Иностранные события» в № 7 «Гражданина» 1874 года (с. 193), где, заметим, он назвал немного иную цифру: 403,000 чел.

${ }^{5}$ Мольтке (Moltke) Хельмут-Карл-Бернхард, граф фон (1800-1891) - полководец, фельдмаршал (с 1871 года), начальник прусского, затем германского генштаба (18571888). Имеется в виду скандальная речь фон Мольтке в рейхстаге 17 февраля (н. ст.) 1874 года, дважды комментировавшаяся в «Гражданине» (см.: Посльдняя страничка (1874. № 6. С. 188); В-ръ П-чб <Пуиъыковичъ В. Ө.>. Иностранныя событія (1874. № 7. C. 193)).

${ }^{6}$ Национал-либеральная партия Германии была создана в 1866 году; в 1870-е годы служила главной опорой правительства О. фон Бисмарка в парламенте. 
и о предстоящемъ распущеніи того самаго рейхстага, который такъ недавно открылся и въ которомъ за правительствомъ, повидимому, было обезпечено значительное большинство ${ }^{1}$. Особенно-же эти тревожные толки о парламентскомъ кризисъ усилились посль того, какъ князь Бисмаркъ 2 (который въ посльднее время, по случаю опасной бользни, совсъмъ удалился отъ дъль ${ }^{3}$ ) заявилъ, въ частномъ разговорь съ депутатами рейхстага, по поводу военнаго закона, что императору остается одно изъ двухъ: или распустить парламентъ, или принять отставку его, Бисмарка, о которой онъ будетъ просить всльдъ за выздоровленіемъ, - и посль того, какъ императоръ подтвердилъ, въ бывшей на дняхъ военной конференціи, свои первоначальныя слова о своей настойчивости въ дьль проведенія военнаго закона. По случаю-же наступившихъ парламентскихъ вакацій, произошелъ перерывъ занятій парламентской коммиссіи. Этимъ воспользовались оффиціозные и сочувствующіе правительству органы печати и подняли сильную агитацію въ пользу безусловнаго принятія военнаго закона, взывая къ патріотизму германцевъ...

Заслуживаетъ вниманія, еще одно событіе въ Германіи. Рейхстагъ, передъ закрытіемъ засъданій по случаю вакацій, утвердилъ предложеніе относительно обязательнаго введенія гражданскаго брака во всей Германіи, недавно введеннаго въ Пруссіи .

Почти одновременно съ чествованіемъ, въ объединенной Германіи, годовщины дня рожденія императора Вильгельма, 11 (23) марта въ объединенной Италіи происходило еще большее торжество: тамъ праздновали двадцатипятильтній юбилей восшествія на престоль короля Виктора-Эммануила ${ }^{5}$ который получиль самыя дружескія поздравленія отъ европейскихъ государей и правительства американскихъ Соединенныхъ Штатовъ и восторженныя заявленія сочувствія отъ всъхъ концовъ Италіи,

${ }^{1}$ Заседания общегерманского рейхстага второго созыва открылись в Берлине 5 февраля (н. ст.) 1874 года. Национал-либеральная партия получила в рейхстаге 261 место, парламентская оппозиция - 136 мест.

${ }^{2}$ Бисмарк-Шёнхаузен (Bismarck-Schönhausen) Отто-Эдуард-Леопольд фон (18151898) - прусский и немецкий государственный деятель, объединитель Германии, имперский канцлер в 1871-1890 годах. Княжеский титул получил в 1871 году.

${ }^{3} \mathrm{O}$ ходъ болъзни кн. Бисмарка до сихъ поръ получаются противоръчивыя извъстія. По однимъ онъ опасно больнъ и никакого улучшенія незамътно. По другимъ - кризисъ миновалъ, и есть надежда, что канцлеръ, черезъ двъ-три недъли, въ состояніи будетъ приступить къ занятію дълами (Примеч. В. Ф. Пуиьюковича).

4 Закон о гражданском браке был принят в Пруссии 9 марта (н. ст.) 1874 года; в конце того же месяца рейхстаг распространил его действие на всю Германию.

${ }^{5}$ Виктор-Эммануил Савойский (di Savoia, 1820-1878) - король Сардинии в 18491861 годах, с 1861 года - король единой Италии. 
не исключая и населенія самаго Рима. Самъ Пій $\mathrm{IX}^{1}$ не замедлилъ почтить короля присылкою поздравленія, на которое посльдній поспъшилъ отправить благодарственное письмо. Разумъется, почти всъ поздравленія отъ подданныхъ, выраженныя разными народными представительствами и представителями, сводились къ выраженію признательности юбиляру за великое дъло объединенія Италіи, перенесенія столицы объединеннаго королевства въ «Въчный городъ» и за осуществленіе принципа «свободная церковь въ свободномъ государствъ».

Мы уже говорили о возникающей и въ католической Австріи борьбъ государственной власти съ церковною (см. № 10)ㄹ․ НЂтъ сомнънія, что борьба эта увеличивается.

При второмъ чтеніи новаго церковнаго законопроекта, парламентъ 13 марта утвердилъ его согласно съ предложеніями коммисіи. А ми нистръ-президентъ, князь Ауерспергъ ${ }^{3}$, съ согласія самого императора, заявилъ, что правительство будетъ энергически пресльдовать и прекращать противозаконную оппозицію, со стороны ультрамонтановъ, новымъ церковнымъ законамъ. Въ томъ же смыслъ сдълаль заявленіе въ палатъ и министръ духовныхъ дълъ 4 . 16 (28) же марта въ палату депутатовъ внесено нъсколькими членами предложеніе о приглашеніи правительства представить въ рейхсратъ проектъ закона объ изгнаніи изъ Австріи іезуитовъ и сопричастныхъ къ нимъ монашескихъ орденовъ.

Между тьмъ въ вънской газетъ «Volks-Freund» появился протестъ австрійскихъ архіепископовъ и епископовъ противъ проектовъ церковныхъ законовъ. Епископать протестуетъ противъ разныхъ постановленій проектовъ, особенно противъ предполагаемаго введенія въ Австріи гражданскаго брака и указываетъ на примъръ Франціи, гдъ, будто бы, введеніе гражданскаго брака вызываетъ всеобщее неудовольствіе. Во всякомъ случаъ, австрійскій епископатъ, является нъсколько умъреннъе прусскаго въ борьбъ съ государственною властью, - по крайней мъръ вышеупомянутый протестъ оканчивается сльдующимъ заявленіемъ: «мы признаемъ

${ }^{1}$ Пий IX, в миру Джованни-Мария Мастаи-Ферретти (Mastai-Ferretti), граф (1792-1878) - папа римский в 1846-1878 годах.

${ }^{2}$ Отсылка к «Иностранным событиям» В. Ф. Пуцыковича в № 10 «Гражданина» от 11 марта 1874 года (с. 284).

${ }^{3}$ Ауэршперг (Auersperg) Адольф фон (1821-1885) - австрийский государственный деятель, с 1867 года ландтагмаршал в Богемии (Чехии). После отставки правительства К.-С. Гогенварта (1871) возглавил новый кабинет, провел законы об избирательной реформе и преобразовании высшего судебного управления. С 1879 года в отставке.

${ }^{4}$ Министром духовных дел (более точное название должности: министр просвещения и культов) в правительстве А. фон Ауэршперга был Карл-Эдлер Штремайр (Stremayr, 1823-1904), юрист, администратор, в 1879 году сменивший фон Ауэршперга в должности министра-президента. 
основанное на конкордатъ требованіе справедливости не утратившимъ своей силы и готовы исполнять то, чего потребуетъ отъ насъ государственная власть, - на сколько эти требованія не будуть противорьчить конкордату. Но мы никогда не подчинимся тюмз притязаніямб, которья оказались бы опасными для блага иеркви»... Что касается іезуитовъ, то и съ ними не такъ легко справиться въ Австріи, какъ это можно было думать. Недавнія пренія въ палать депутатовъ относительно предложенія о закрытіи богословскаго факультета въ инспрукскомъ университеть ${ }^{1}$, какъ разсадника іезуитства въ Австріи, доказали, что іезуиты еще сильны въ Австріи. Правительство, въ лицъ министровъ, защищало инспрукскій іезуитскій факультетъ, и тьмъ ободрило іезуитовъ...

Вся современная политическая жизнь Франціи сосредоточивается на двухъ достойныхъ вниманія событіяхъ: на борьбъ такъ называемаго «національнаго» собранія съ самою націею, избравшею его, и на борьбъ правительства, т. е. кабинета исполнительной власти, съ разными партіями національнаго собранія, и между прочимъ съ партіями - избравшими главу этой самой исполнительной власти. Фактическая сторона дъла такова. Окровавленная, истощенная и связанная по рукамъ и ногамъ нъмецки-

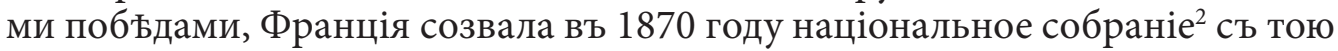
цьлью, чтобы оно развязалось какъ нибудь съ врагомъ. Благодаря преимущественно усиліямъ пользовавшагося европейскимъ довъріемъ Тьера ${ }^{3}$, co- $^{-}$ браніе расквиталось съ Германіею; но, вкусивъ сладость власти, положило не разставаться съ нею, т. е. не расходиться, не смотря на окончаніе своей миссіи и на постоянные отчаянные протесты страны противъ этого. И теперь страна дълаетъ всякія усилія, чтобы только развязаться со своимъ національнымъ собраніемъ! Тоже самое случилось и съ нынбшнимъ правительствомъ. Получивъ исполнительную власть изъ рукъ монархическаго большинства собранія, маршалъ Макъ-Магонъ, въ лицъ своего перваго министра, герцога Брольи ${ }^{4}$, ведеть теперь борьбу съ нбкоторыми партіями этого большинства, постоянно подкапывающимися подъ его власть, ввЂренную ему ими самими на семь льтъ.

${ }^{1}$ Инспрук или Инсбрук - главный город австрийской коронной земли Тироль. Инсбрукский университет имени Леопольда-Франца был основан в 1677 году на базе иезуитского коллегиума, существовавшего с 1552 года.

${ }^{2}$ Неточность: Национальное собрание было созвано 15 февраля (н. ст.) 1871 года.

${ }^{3}$ Тьер (Thiers) Луи-Адольф (1797-1877) - французский историк, политический деятель, первый президент III Республики (1871-1873).

${ }^{4}$ Мак-Магон (Mac-Mahon) Эдм-Патрис-Морис (1808-1893) - маршал-бонапартист, второй президент III Республики (1873-1879). Брольи (правильнее: Бройль) (Broglie) Жак-Виктор-Альбер, герцог де (1821-1901) - французский государственный деятель, сторонник орлеанской королевской династии. В 1873-1874 и 1877 годах возглавлял кабинет министров. Упомянут Достоевским в «Иностранных событиях» в №o 41 и 46 «Гражданина» за 1873 год. 
Самымъ красноръчивымъ подтвержденіемъ вражды націи со своимъ національнымъ собраніемъ служатъ дополнительные выборы: не смотря на то, что такіе выборы производились уже много разъ, на мъста выбывшихъ изъ собранія депутатовъ, всегда побъда оставалась за республиканскими кандидатами въ значительномъ большинствъ голосовъ. Такъ на посльднихъ выборахъ, 18 (30) марта, въ департаменть Жиронды, республиканецъ Рудье получилъ 71,000 голосовъ, тогда какъ его противники получили: бонапартистъ 47,000 гол., а консерваторъ 23,000 гол. ${ }^{1}$; въ департаменть-же Верхней-Марны республиканецъ Данель получилъ 36,000 гол. ${ }^{2}$ противъ консерватора, получившаго лишь 24,000 гол... НБтъ полнаго основанія утверждать, на основаніи такихъ результатовъ выборовъ, что Франція страна чисто-республиканская, такъ какъ извъстно, что посль республикъ французская нація не разъ высказывалась (разными способами) и за монархію. Но несомнънно, однакоже, изъ этихъ выборовъ, что Франція крайне враждебно относится къ своему нынъшнему собранію, съ такимъ неслыханнымъ и несвойственнымъ народному представительству насиліемъ навязывающему ей свою учредительную власть и отжившія во Франціи традиціи, и уничтожающему всякое народное самоуправленіе ${ }^{3} . .$.

Что касается борьбы правительства съ разными партіями собранія, то эта борьба въ посльднее время стала принимать угрожающее направленіе. Едва успъло монархическое большинство собранія рбшить (въ ноябръ) вопросъ о продленіи полномочій главы исполнительной власти

${ }^{1}$ Жиронда - департамент в юго-западной части Франции, главный город Бордо. Рудье (Roudier) Бернар (1823 - после 1877) - адвокат, депутат Национального собрания. Возможно, в обозрении «Иностранные события» использованы предварительные результаты выборов: по данным энциклопедии П. Ларусса, на дополнительных выборах по округу Жиронды 29 (а не 30) марта (н. ст.) 1874 года Б. Рудье получил 68877 голосов (см.: Larousse P. Grand dictionnaire universel. Paris, [1877]. T. 16. P. 1187). Противниками Б. Рудье на выборах были бонапартистский генерал А.-А. Бертран (Bertrand) и вице-адмирал Г.-Л.-Э. Ларьё (Larrieu), консерватор; последний получил около 24 000, а не 23000 голосов (Ibid. P. 1040).

2 Верхняя Марна - департамент, включающий некоторые территории Шампани и Бургундии; главный город - Шомон. Данель-Бернарден (Danelle-Bernardin) ЖанБатист-Фернан (1826 - после 1888) - крупный французский промышленник, член генерального совета Верхней Марны, консервативный республиканец. Был избран депутатом Национального собрания 29 марта (н. ст.) 1874 года, получив около 35000 (а не 36000 ) голосов (см.: Larousse P. Op. cit. P. 635).

320 января (н. ст.) 1874 года Национальное собрание приняло внесенный кабинетом Ж.-В.-А. де Бройля закон о мэрах. По новому закону право назначения на должности мэров и их помощников было передано правительству и его агентам - префектам. 
на семь льтъ ${ }^{1}$, какъ начались нескончаемые споры и интриги между самими же монархическими партіями, продлившими власть, объ этой самой продленной власти. Напрасно маршаль Макъ-Магонъ заявилъ, при посъщеніи коммерческаго суда, что онъ оградитъ свою власть отъ всякихъ покушеній противъ нее. Нападки легитимистовъ и бонапартистовъ не переставали раздаваться противъ этой власти. Дьло даже дошло до того что радикалы явились косвенными защитниками власти маршала. Какъ извъстно, вопросъ радикальной партіи сдъланъ быль относительно допущенія министерствомъ подкапыванья монархистовъ подъ существующій порядокъ, а сльдовательно и семильтнюю власть президента республики. Но это не разъяснило дъла. Въ то же самое засъданіе легитимистъ Казеновъ-де-Прадинъ ${ }^{2}$ заявилъ, что онъ понимаетъ законъ о продленіи полномочій не болье какъ переходъ къ монархіи, и скомпрометировалъ Макъ-Магона, увъряя, что онъ тотчасъ же долженъ уступить свое мъсто королю, еслибъ посльдовало возстановленіе монархіи. Почти одновременно съ этимъ происходила и бонапартистская демонстрація по случаю совершеннольтія императорскаго принца ${ }^{3}$, который въ своей рьчи ясно опредълиль, что маршаль Макъ-Магонъ, товарищъ побъдъ и несчастій его отца, долженъ уступить свое мъсто ему, принцу, лишь только окажется удобное время посль имъющаго быть народнаго голосованія. Хотя герцогъ Брольи отвъчаль на первое заявленіе, что это личное мнъніе Прадина, нисколько не обязывающее правительство, а на второе - лишь отставками должностныхъ лицъ изъ бонапартистовъ, Ђздившихъ къ императорскому принцу; но отъ этого дъла не улучшились. Точно также не подъйствовало и письмо къ Брольи самого Макъ-Магона, поспьшившаго заявить, что онъ вполнъ одобряетъ заявленія его во время запроса радикаловъ и напомнившаго свою угрозу, произнесенную въ коммерческомъ судъ, относительно того, что онъ, маршалъ, съумъетъ оградить свою продленную власть отъ нападенія разныхъ партій.

Походъ противъ семильтнихъ полномочій снова начался со стороны нетерпъливыхъ насчетъ пріъзда «короля» монархистовъ. Легитимистъ

${ }^{1}$ См. «Иностранные события» Достоевского от 12 ноября 1873 года (Д30, т. 21, с. 230-233).

${ }^{2}$ Казенов де Прадин (Cazenove de Pradines) Пьер-Мари-Эдуар де (1838-1896) политический деятель, волонтер во время войны 1870-1871 годов, затем депутат-легитимист.

${ }^{3}$ Принц Эжен-Луи-Жан-Жозеф Бонапарт (Bonaparte, 1856-1879) - единственный сын Наполеона III и императрицы Евгении. После сентябрьской революции 1870 года жил в Англии в Чизлхёрсте. 16 марта (н. ст.) 1874 года бонапартисты отпраздновали совершеннолетие принца, провозгласив его Наполеоном IV. В 1879 году принц был убит во время войны англичан с зулусами. 
виконтъ д’Абовиль ${ }^{1}$, говоря о письмъ Макъ-Магона, написанномъ по поводу заявленія Прадина, обвиняетъ Брольи въ томъ, что онъ замышляетъ семильтнюю республику и уничтожаетъ плоды низверженія Тьера, и, сверхъ того, прямо нападаетъ на самого Макъ-Магона, увъряя, что маршалъ глубоко огорчилъ «своихъ настоящихъ друзей», которыхъ, четыре мъсяца тому назадъ, увђрялъ въ своемъ сочувствіи и относительно которыхъ не сдержалъ своихъ объщаній. Извъстный уже легитимистъ маркизъ Франльё 2 раздраженный, тъмъ, что ему президентъ собранія не далъ о чемъ-то говорить, напечаталъ угрозу относительно того, что въ маъ, послъ вакацій, онъ, имъя въ виду прецедентъ отмъны собраніемъ своихъ же недавнихъ ръшеній, сдъланной собраніемъ наканунъ, при отмънъ закона о муниципальныхъ совътахъ, напомнитъ депутатамъ о необходимости отмънить рЂшеніе, принятое ими 20 ноября, относительно семилътней власти и заставитъ депутатовъ «положить конецъ временному правленію, котораго Франція не можетъ долъе терпъть». Независимо отъ этого еще одинъ легитимистъ, Дагирель ${ }^{3}$, нападая съ трибуны на семильтнія полномочія, внесъ предложеніе, прямо направленное противъ существующаго правительства: о томъ, чтобы собраніе не позже 1 іюня высказалось въ пользу какой нибудь окончательной формы правленія. Наконецъ, по случаю наступившихъ вакацій собранія, возобновились, по примъру прошлаго года, интриги и сношенія монархистовъ съ графомь Шамборскимъ. Уже на послъднихъ засъданіяхъ отсутствовали нъкоторые легитимисты. Носятся слухи, въ парижскихъ газетахъ, что Казеновъ-де-Прадинъ, извъстный Люсьенъ Бренъ ${ }^{4}$ и другіе приближенные къ главъ Бурбоновъ и уполномоченные роялистами уже отправились въ Фросдорфь ${ }^{5}$ для окончательнаго соглашенія «съ королемъ».

${ }^{1}$ Абовиль (Aboville) Огюст-Эрнест, виконт д’ (1819-после 1876) - французский консервативный политик. В 1858-1861 годах был мэром г. Глюкса в департаменте Ньевр. В 1871-1875 годах - депутат Национального собрания.

${ }^{2}$ Франльё (Franclieu) Поль-Пакье, маркиз де (1810-1877) - политик-легитимист, депутат Национального собрания, затем сенатор. Упомянут В.Ф. Пуцыковичем в «Иностранных событиях» в № 4 «Гражданина» от 29 января и в № 7 от 18 февраля 1874 года.

${ }^{3}$ Дагирель (Dahirel) Франсуа-Гиасент-Мари (1804-1875) - адвокат, депутат Национального собрания, роялист.

${ }^{4}$ Брен (Brun) Люсьен (1822-1898) - лионский адвокат, один из вождей легитимистов в Национальном собрании 1871-1875 годов. В октябре 1873 года вместе с П.-Ш. Шенелоном ездил на переговоры с графом де Шамбором в Зальцбург.

${ }^{5}$ Фросдорф или Фрошдорф - замок в Австрии, местожительство французского претендента графа де Шамбора. 
Такимъ образомъ, какъ власть собранія, такъ и «упроченная на семь льтъ власть» Макъ-Магона постоянно, и особенно впродолженіи нъсколькихъ посльднихъ дней подрядъ, сильно колебались самими-же монархистами.

По извъстіямъ изъ Испаніи, полученнымъ въ посльдніе дни, но недостовърнымъ, оказывается, что происходили двъ большія битвы между карлистами и войсками правительства ${ }^{1}$. Происходила битва, въ которой, по карлистскимъ извъстіямъ, республиканцы потеряли, будто бы, до 6,000 чел., въ томъ числь 1,500 пльнными, а сами карлисты - лишь 1,500 чел. По сообщеніямъ же изъ лагеря Соморостро ${ }^{2}$, происходила битва подъ Бильбао, въ которой республиканцы насчитываютъ изъ своихъ убитыми до 300 чел. и ранеными до 1,400 чел. Во всякомъ случаъ о силь междоусобной войны можно судить по тому, что сами главные начальники республиканскихъ войскъ, принимаютъ энергическое участіе въ бою и подаютъ примъры храбрости: генералъ Примо-де-Ривера смертельно раненъ ${ }^{3}$, генералъ Лома ${ }^{4}$ тоже получилъ опасную рану, а генералъ

${ }^{1}$ Речь идет о событиях II Карлистской войны (1873-1876). Карлистские войны династические и гражданские войны, происходившие в Испании в 1830-е и 1870е годы. Карлисты - первоначально сторонники испанского претендента дон Карлосастаршего (1788-1855) - брата короля Фердинанда VII Бурбона. В 1833 году дон Карлос-старший заявил свои права на престол и развязал I Карлистскую войну (продолжалась до 1840 года). В дальнейшем претендентами от карлистской ветви Бурбонов были сыновья дон Карлоса: Карлос-Луис, граф Монтемолин (1818-1861), дон Хуан (1822-1887), - а также внук дон Карлос-младший (1848-1909); последний предъявил право на престол в 1868 году. В 1869, 1870 и 1872 годах сторонники дон Карлоса-младшего подняли три мятежа в северной Испании, а в 1873 году начали II Карлистскую войну. Карлистам противостояли в 1870-е годы силы республиканского правительства, с 1875 года - сторонники нового короля Альфонса XII (18571885).

${ }^{2}$ Соморостро - лагерь правительственных войск под Бильбао в северной Испании в период II Карлистской войны.

${ }^{3}$ Примо де Ривера-и-Собремонте (Primo de Rivera y Sobremonte) Фернандо (1831-1921) - военачальник, участник многих сражений II Карлистской войны. Приводимые В. Ф. Пуцыковичем сведения о «смертельном» ранении генерала Примо де Ривера неточны.

${ }^{4}$ Лома-и-Аргуэллес (Loma y Argüelles) Хосе-Мария (1822-1893) - испанский полководец, участник I и II Карлистских войн, марокканской кампании 1859-1860 годов. С 1878 года носил титул маркиза дель Ориа. 
Топете ${ }^{1}$ чуть было не попался въ руки непріятеля; самъ главнокомандующій르룔галъ свою жизнь большой опасности, причемъ рядомъ съ нимъ убитъ его трубачъ.

$$
\text { В-ръ П-чъ. }
$$

\section{КОММЕНТАРИЙ}

Рубрика «Иностранные события» была открыта Достоевским в газете-журнале «Гражданин» 17 сентября 1873 года. Достоевскому принадлежат выпуски «Иностранных событий» в №o 38-46, 51, 521873 года и в № 11874 года. В январе 1874 года писатель передал рубрику секретарю редакции «Гражданина» В. Ф. Пуцыковичу.

Композиционные особенности, лексико-стилистическое оформление обозрения «Иностранные события» в № 12 журнала от 25 марта 1874 года, наличие в публикации идейно-тематических параллелей с одним из прошлогодних выпусков «Иностранных событий» Ф. М. Достоевского (1873. № 42) дают основание предположить анонимное участие Достоевского в написании материала. Достоевскому может быть атрибутирован французский сюжет обозрения ${ }^{15)}$ («Вся современная политическая жизнь Франціи <...> сильно колебались самими-же монархистами»).

Основания для атрибуции:

1. Контраст стилистического оформления французского сюжета с обычным сухим и деловым - стилем В.Ф. Пуцыковича (который ощутим, в частности, в остальных сюжетах обозрения в № 12). Французский раздел написан раскованным, свободным слогом; текст обильно насыщен метафорами и публицистическими образами: «Окровавленная, истощенная и связанная по рукамъ и ногамъ нъмецкими побъдами, Франція созвала въ 1870 году національное собраніе съ тою цълью, чтобы оно развязалось какъ нибудь съ врагомъ»; «собраніе расквиталось съ Германіею; но, вкусивъ сладость в ласти, положило не разставаться съ нею <..> не смотря на окончаніе своей миссіи и на постоянные о т чаян ны е протесты страны противъ этого. И теперь страна дълаетъ всякія усилія, чтобы только развязаться со своимъ національнымъ собраніемъ!» (разрядка наша. - A. О.). Изложение событий сопровождается меткими, емкими ироническими замечаниями, напр.: «борьба такъ называемаго “національнаго" собранія съ самою націею, избравшею его». Стилистическое

${ }^{1}$ Неточность: речь идет об адмирале Топете-и-Карбальо (Topete y Carballo) ХуанеБатисте (1821-1885) - военном и государственном деятеле Испании. В период II Карлистской войны Х.-Б. Топете-и-Карбальо отличился в сражениях при Абанто и Соморостро.

${ }^{2}$ Должность главнокомандующего испанской армией с марта 1874 года исполнял президент Испании маршал Франсиско Серрано-и-Домингес (Serrano у Domínguez, 1810-1885). 
своеобразие французского сюжета обозрения трудно объяснить даже глубокой редакторской правкой рукописи Пуцыковича Достоевским.

2. Во французском сюжете имеются идейно-тематические соответствия с «Иностранными событиями» Достоевского в № 42 «Гражданина» от 15 октября 1873 года. Сравним комментарий в обоих обозрениях к известиям о победах республиканских кандидатов на дополнительных выборах во французское Национальное собрание. 1874, № 12: «Нътъ полнаго основанія утверждать, на основаніи такихъ результатовъ выборовъ, что Франція страна чисто-республиканская, такъ какъ извъстно, что посль республикъ французская нація не разъ высказывалась (разными способами) и за монархію». 1873, № 42: «Недавние выборы на четыре вакантные места в Собрании огромным большинством разрешились в пользу республиканцев <..> Это не значит, что французы так вдруг пожелали теперь республики, а значит лишь то, как испугались они восстановления “законной монархии”» (Д30, т. 21, с. 209). Резко негативная оценка деятельности монархического большинства Национального собрания в обозрении в № 121874 года также имеет соответствие в «Иностранных событиях» в № 42 за предыдущий год. 1874, № 12: «...Франція крайне враждебно относится къ своему нынбшнему собранію, съ такимъ неслыханнымъ и несвойственнымъ народному представительству насиліемъ навязывающему ей <..> отжившія во Франціи традиціи». 1873, № 42: «...Национальное собрание <..> перестало выражать собою истинную волю страны, а стало быть, власть его в настоящее время - одно злоупотребление <...> Собрание оскорбляет нацию и ввергает всех здравомыслящих людей в удивление <..> что несколько своевольных людей, против воли всей Франции, могут <..> навязать ей ненавистный образ правления» (там же).

3. Претендент на французский трон от легитимистов граф де Шамбор в обозрении в № 121874 года именуется графом Шамборским. Подобное русское переложение титула comte de Chambord очень характерно для Достоевского. Но оно разнится с общепринятым русским написанием этого титула; такой вариант не встречается в публицистике В. Ф. Пуцыковича и, за весьма редкими исключениями, не принят в русской прессе XIX века.

4. В обозрении в № 121874 года примечательно перечисление без какого-либо информационного повода ряда тем и фактов, уже рассмотренных В. Ф. Пуцыковичем в январских-мартовских выпусках «Иностранных событий»:

— «Едва успьло монархическое большинство собранія рбшить (въ ноябрь) вопросъ о продленіи полномочій главы исполнительной власти на семь льтъ, какъ начались нескончаемые споры и интриги между самими же монархическими партіями, продлившими власть» (сюжет подробно описан в «Иностранных событиях» в № 4 «Гражданина» 1874 года, см. указанный номер, с. 103-105);

- «Напрасно маршалъ Макъ-Магонъ заявилъ, при посъщеніи коммерческаго суда, что онъ оградитъ свою власть отъ всякихъ покушеній противъ нее» (упоминалось в «Иностранных событиях» в № 71874 года, см. указанный номер, с. 194); 
- «Дьло даже дошло до того что радикалы явились косвенными защитниками власти маршала $<\ldots .>$ вопросъ радикальной партіи сдъланъ былъ относительно допущенія министерствомъ подкапыванья монархистовъ подъ существующій порядокъ» (история с депутатским запросом радикалов поэтапно изложена в «Иностранных событиях» в №№ 4, 7, 101874 года — см. с. 105, 196, 283 в годовом комплекте «Гражданина»);

- «...происходила $<\ldots>$ демонстрація по случаю совершеннолътія императорскаго принца, который въ своей ръчи ясно опредълилъ, что маршалъ Макъ-Магонъ, товарищъ побъдъ и несчастій его отца, долженъ уступить свое мъсто ему, принцу» (упоминалось в «Иностранных событиях» в № 10 «Гражданина» 1874 года, см. указанный номер, с. 283).

Повторяя эту информацию, обозреватель не дополняет ее какими-либо новыми подробностями, уточнениями, а лишь подкрепляет ею свою основную мысль: «Вся современная политическая жизнь Франціи сосредоточивается <...> на борьбъ такъ называемаго "національнаго” собранія съ самою націею, избравшею его, и на борьбъ правительства, т. е. кабинета исполнительной власти < ..> съ партіями - избравшими главу этой самой исполнительной власти». Постоянному автору рубрики для этого достаточно было бы сделать простые отсылки к своим прежним публикациям. Отмеченные смысловые повторы (которых нет больше ни в одном международном обозрении В. Ф. Пуцыковича за период его совместной с Достоевским работы в «Гражданине») свидетельствуют о том, что в устоявшуюся структуру авторской рубрики, по-видимому, вплетается текст другого публициста.

\section{ПРИМЕЧАНИЯ}

1) Ф. М. Достоевский в воспоминаниях современников: в 2 т. М., 1990. Т. 2. C. 255.

2) См.: Литературное наследство. Т. 15. М., 1934. С. 150-151.

3) Инициал П. указан в «Подробном обозначении содержания 52 №№ “Гражданина" за 1873 г.». Сама статья «Неоцененное побуждение» напечатана в № 45 без подписи.

4) Кроме А. У. Порецкого, инициал фамилии П. подходит еще двум участникам редакционного кружка «Гражданина» 1873-1874 годов - В.Ф. Пуцыковичу и К. П. Победоносцеву. Однако в указанный период ни тот, ни другой сотрудник не подписывали свои публикации этим инициалом. Показательна также тематическая чужеродность статьи «Семейная неурядица...» публицистике К. П. Победоносцева.

5) Глубокая правка рукописей, вплоть до «пересочинения» текста статьи заново, была обычной практикой Достоевского-редактора. «...Имея статью и решив напечатать, - переправлять ее с начала до конца, что зачастую приходится. Литературные сценки Генслера (в сегодняшнем №) я почти вновь пересочинил», - сообщал Достоевский, в частности, М. П. Погодину 26 февраля 1873 года (Д30, т. 29, кн. 1, с. 262). 
6) Стиль «Семейной неурядицы...» - также дополнительный аргумент против атрибуции материала как К. П. Победоносцеву, так и В. Ф. Пуцыковичу.

7) Повод уйти из жизни у героини Порецкого (несчастье в любви) был не более веским, чем у сестер-охтянок в «Семейной неурядице...». Порецкий-обозреватель сообщает и другую красноречивую (особенно для читателей консервативного «Гражданина») подробность: вынутая из петли незадачливая девятнадцатилетняя самоубийца в присутствии священника произносит «оскорбительныя для вЂрующихъ слова на Бога и все святое». Вот, однако, комментарий обозревателя: «На сльдствіи “преступница” показала, что она не помнитъ тъхъ преступленій, въ которыхъ ее обвиняютъ. Мы не знаемъ, была-ли уже она судима и какъ отнесся судъ къ преступленію, совершенному только-что вынутою изъ петли». Личность девушки представлена в обозрении как «страдальческий образ» из народной среды (Гражданин. 1873. № 49. С. 1314).

8) См.: Гражданин. 1873. № 49. С. 1314-1315.

9) В данном случае не идет речь об использовании жирного шрифта в редакционных объявлениях и рекламе.

10) Из 23 таких публикаций 13 принадлежат бесспорно Мещерскому, 3 бесспорно Достоевскому, 2 представляют собой обращенные к Мещерскому (и, очевидно, им же подготовленные к печати) открытые письма читателей. В числе 5 «оставшихся» (неатрибутированных) текстов - одна передовая статья, три выпуска рубрики «Последняя страничка» и одна рецензия в отделе «Библиография». При этом несомненны, во-первых, принадлежность Мещерскому почти всех передовых статей журнала, во-вторых, активное участие как Мещерского, так и Достоевского в подготовке «Последней странички».

11) Позднее о самоубийстве Е. Гейденрейх в «Гражданине» напишет И. Ю. Некрасов (рубрика «Из Москвы»). Московский корреспондент (публицист четко выраженного консервативно-славянофильского направления) выскажет «глубокое состраданіе» несчастной девушке, ставшей жертвой легкомысленного увлечения «человъкомъ недостойнымъ» (Гражданин. 1873. № 40. С. 1070).

12) Этот прием, например, помог опознать как текст Достоевского статью «Разъяснение некоторых сторон вопроса о нуждах единоверия» в № 24 «Гражданина» 1874 года $[5,20]$.

13) В цитированных статьях выражение употреблено в близких контекстах: в оправдании самоубийства и в отрицании «нечаевщины» как явления «во что бы <то> ни стало» упрекается либеральная пресса.

14) При обилии в каждом номере «Гражданина» упоминаний о газетах и ссылок на газеты такое особенное выражение, как «газетная печать (пресса)» в журнале практически не встречается.

15) Отметим, что в бытность Достоевского ведущим «Иностранных событий» французская тематика занимала в рубрике центральное место. Известиям из Франции посвящено около двух третей общего объема 12 выпусков «Иностранных событий» Достоевского. 


\section{СПИСОК ЛИТЕРАТУРЫ}

1. Архипова, А. В. Достоевский и Кишенский / А. В. Архипова // Достоевский. Материалы и исследования. - Т. 2. - Ленинград : Наука, 1976. —С. 199-207.

2. Бельчиков, Н. Ф. Достоевский о Тютчеве / Н. Ф. Бельчиков // Былое. - 1925. — № 5. C. $155-162$.

3. Битюгова, И. А. Достоевский - редактор стихотворений в «Гражданине» / И. А. Битюгова // Достоевский. Материалы и исследования. - Т. 6. - Ленинград : Наука, 1985. - С. 241-251.

4. [Викторович, В. А.] Ф. М. Достоевский. Новоатрибутированные статьи 1872-1874 гг. (Атрибуция и научный комментарий доктора филологических наук В. Викторовича) / В. А. Викторович // Знамя. - 1996. - № 11. - С. 151-177.

5. Викторович, В. А. Достоевский в Обществе любителей духовного просвещения / В. А. Викторович // Достоевский и мировая культура. - 2004. - № 20. - С. 9-39.

6. Викторович, В. А. Достоевский. Коллективное. «Гражданин» как творчество редактора / В. А. Викторович // Неизвестный Достоевский [Электронный ресурс] : международный электронный журнал. - 2015. - № 4. - C. 11-20. - URL : http:// unknown-dostoevsky.ru/files/redaktor_pdf/1453710211.pdf (31.05.2016).

7. Виноградов, В. [В.] И. С. Генслер и Ф. М. Достоевский - редактор «Гаванских сцен» / В. В. Виноградов // Русская литература. - 1964. - № 2. - С. 71-91.

8. Виноградов, В. В. Проблема авторства и теория стилей / В. В. Виноградов. - Москва : Гослитиздат, 1961. - 614 с.

9. Гроссманъ, Л. [П.] Предисловіе / Л. П. Гроссман // Достоевскій, Ө. М. Полное собраніе сочиненій : в XXIII т. / Ф.М.Достоевский. - Санктпетербургъ ; Петроградъ : Просвьщеніе, 1911-1918. - Т. XXII. - Петроградъ, 1918. - С. VII-XXX.

10. Захаров, В. Н. Вопрос об А. С. Хомякове в журнале братьев Ф. М. и М. М. Достоевских «Время» / В. Н. Захаров // А. С. Хомяков - мыслитель, поэт, публицист : сб. науч. тр. - Москва, 2007. - Т. 1. - С. 305-320.

11. Захаров, В. [Н.] Гениальный фельетонист / В.Н.Захаров // Достоевский, Ф. М. Полное собрание сочинений : канонические тексты / Ф. М. Достоевский. - Т. 4. Петрозаводск : Изд-во ПетрГУ, 2000. - С. 801-822.

12. Захаров, В. [Н.] Идеи «Времени», дела «Эпохи» / В. Н. Захаров // Достоевский, Ф. М. Полное собрание сочинений : канонические тексты / Ф. М. Достоевский. - Т. 5. Петрозаводск : Изд-во ПетрГУ, 2004. - С. 695-712.

13. Захаров, В.Н. Триумф анонимного Автора / В.Н. Захаров // Достоевский, Ф. М. Полное собрание сочинений : в 18 т. / Ф. М. Достоевский. - Москва : Воскресенье, 2003-2007. - T. 5. - 2004. - С. 521-539.

14. Летопись жизни и творчества Ф. М. Достоевского : в 3 т. - Санкт-Петербург : Академический проект, 1993-1995. - Т. II. - 1994. - 587 с.

15. Нечаева, В. С. Журнал М. М. и Ф. М. Достоевских «Эпоха». 1864-1865 / В. С. Нечаева. Москва : Наука, 1975. - 304 с.

16. Отливанчик, А. В. Ф. М. Достоевский и международных событий в «Гражданине» (1873 г. - апрель 1874 г.) / А. В. Отливанчик // Достоевский и современность. Материалы XXIII Международных Старорусских чтений 2008 года. - Ч. I. - Великий Новгород, 2009. - С. 273-283. 
17. Отливанчик, А. [В.] Ф. М. Достоевский $\quad$ - редактор авторских текстов в еженедельнике «Гражданин» (1873-1874 гг.). Новые разыскания и версии / А. В. Отливанчик // Балтика. - Таллин, Эстония, 2010. - С. 69-77.

18. Отливанчик, А. В. Неизвестный текст Достоевского? К вопросу об авторстве статьи «Семейная неурядица как причина самоубийства» («Гражданин», 1873 г., № 49) / А. В. Отливанчик // Достоевский и современность. Материалы ХХІ Международных Старорусских чтений 2006 года. - Великий Новгород, 2007. - С. 217-233.

19. [Томашевский, Б. В.] Достоевский-редактор / Б. В. Томашевский // Достоевский, Ф. М. Полное собрание художественных произведений : в 13 т. / Ф. М. Достоевский. Москва ; Ленинград : Государственное издательство, 1926-1930. - Т. 13. - 1930. С. 559-593.

20. Туниманов, В. А. Завершение многолетнего труда / В.А. Туниманов // Русская литература. - 1976. - № 2. - С. 199-206.

Alexander V. Otlivanchik

(Minsk, the Republic of Belarus)

AlexOt@yandex.ru

\section{DOSTOEVSKY AS A CO-AUTHOR OF ALEXANDER PORETSKY AND VICTOR PUTSYKOVICH IN «GRAZHDANIN»: Experience of Attribution}

Abstract. The article is devoted to the problem of attribution of publications of the weekly "Grazhdanin" and presents the arguments in favor of the role of Dostoevsky as a co-author of the article "Semeynaya neuryaditsa kak prichina samoubiystva" ["Family problem as a cause of suicide"] ("Grazhdanin". 1873, no. 49; in collaboration with Alexander Poretsky) and the review "Inostrannye sobytiya" ["Foreign events"] ("Grazhdanin". 1874, no. 12; in collaboration with Victor Putsykovich).

Keywords: Fyodor Dostoevsky, Alexander Poretsky, Victor Putsykovich, the weekly journal "Grazhdanin», attribution, editing, co-authorship

\section{References}

1. Arkhipova A. V. Dostoevskiy i Kishenskiy [Dostoevsky and Kishensky]. Dostoevskiy. Materialy $i$ issledovaniya [Dostoevsky. Materials and Researches]. Leningrad, Nauka Publ., 1976, vol. 2, pp. 199-207.

2. Bel'chikov N. F. Dostoevskiy o Tyutcheve [Dostoevksy about Tyutchev]. Byloe. 1925, no. 5, pp. 155-162.

3. Bityugova I. A. Dostoevskiy - redaktor stikhotvoreniy v «Grazhdanine [Dostoevsky as an Editor of the Poems in "Grazhdanin"]. Dostoevskiy. Materialy i issledovaniya [Dostoevsky. Materials and Researches]. Leningrad, Nauka Publ., 1985, vol. 6, pp. 241-251.

4. Viktorovich V. A. F. M. Dostoevskiy. Novoatributirovannye stat'i 1872-1874 godov (atributsiya i nauchnyy kommentariy V. Viktorovicha) [Fyodor Dostoevsky. Newly Attributed Articles. 1872-1874. (Attribution and Scientific Commentary by V. Viktorovich)]. Znamya, 1996, no. 11 , pp. 151-177. 
5. Viktorovich V. A. Dostoevskiy v Obshchestve lyubiteley dukhovnogo prosveshcheniya [Dostoevsky in the Society of Adherents to the Enlightenment]. Dostoevskiy i mirovaya kul'tura [Dostoevsky and World Culture], 2004, no. 20, pp. 9-39.

6. Viktorovich V. A. Dostoevskiy. Kollektivnoe. «Grazhdanin» kak tvorchestvo redaktora [Dostoevsky. The Collective. "Grazhdanin» as a Creative Work of the Editor]. Neizvestnyy Dostoevskiy. Mezhdunarodnyy elektronnyy nauchnyy zhurnal [The Unknown Dostoevsky: International Electronic Scientific Journal], 2015, no. 4, pp. 11-20. Available at : http:// unknown-dostoevsky.ru/files/redaktor_pdf/1453710211.pdf (accessed 01 July 2016).

7. Vinogradov V. V. I. S. Gensler i Dostoevskiy - redaktor "Gavanskikh stsen» [I. Gensler and Dostoevsky as the Editor of "Havana Scenes"]. Russkaya literatura, 1964, no. 2, pp. 71-91.

8. Vinogradov V. V. Problema avtorstva $i$ teoriya stiley [Authorship Problem and the Theory of Styles]. Moscow, Goslitizdat Publ., 1961. 614 p.

9. Grossman L. P. Predislovie [Preface]. Dostoevskiy F. M. Polnoe sobranie sochineniy : $v 23$ tomakh [Dostoevsky F. M. The Complete Works in 23 vols]. Saint-Petersburg, Petrograd, Prosveshchenie Publ., Petrograd, 1918, vol. 22, pp. 7-30.

10. Zakharov V. N. Vopros ob A. S. Khomyakove v zhurnale brat'ev F. M. i M. M. Dostoevskikh "Vremya» [A Question about A. S. Homyakov in the Magazine "Vremya" of the Brothers Fyodor and Mikhail Dostoevsky]. A.S. Khomyakov - myslitel', poet, publitsist [A. Khomyakov is a Thinker, Poet, Publicist]. Moscow, 2007, vol. 1, pp. 305-320.

11. Zakharov V. N. Genial'nyy fel'etonist [The Brilliant Feuilletonist]. Dostoevskiy F. M. Polnoe sobranie sochineniy: kanonicheskie teksty [Dostoevsky F. M. The Complete Works: Canonical Texts]. Petrozavodsk, Petrozavodsk State University Publ., 2000, vol. 4, pp. 801-822.

12. Zakharov V. N. Idei «Vremeni», dela «Epokhi» [Ideas of “Time”, Deeds of "Epokha”]. Dostoevskiy F. M. Polnoe sobranie sochineniy : kanonicheskie teksty [Dostoevsky F.M. The Complete Works: Canonical Texts]. Petrozavodsk, Petrozavodsk State University Publ., 2004, vol. 5, pp. 695-712.

13. Zakharov V. N. Triumf anonimnogo Avtora [The Triumf of an Anonymous Author]. Dostoevskiy F. M. Polnoe sobranie sochineniy : v 18 tomakh [Dostoevsky F. M. The Complete Works in 18 vols]. Moscow, Voskresen'e Publ., 2004, vol. 5, pp. 521-539.

14. Letopis' zhizni i tvorchestva F. M. Dostoevskogo : v III tomakh [The Chronicle of Dostoevsky's life and works in 3 vols]. Saint-Petersburg, Akademicheskiy proekt Publ., 1994, vol. II. 587 p.

15. Nechaeva V. S. Zhurnal M. M. i F. M. Dostoevskikh «Epokha». 1864-1865 [The Magazine of Mikhail and Fyodor Dostoevsky "Epokha". 1864-1865]. Moscow, Nauka Publ., 1975. 304 p.

16. Otlivanchik A. V. F. M. Dostoevskiy i V. F. Putsykovich - obozrevateli mezhdunarodnykh sobytiy v «Grazhdanine» (1873 g. - aprel’ 1874 g.) [F. M. Dostoevsky and V. F. Putsykovich as Reviewers of International Events in "Grazhdanin" (1873 - April 1874)]. Dostoevskiy $i$ sovremennost'. Materialy XXIII Mezhdunarodnykh Starorusskikh chteniy 2008 goda [Dostoevsky and Modern Age: Proceedings of the 23d International Readings in Old Russian Culture, 2008]. Velikiy Novgorod, 2009, part I, pp. 273-283.

17. Otlivanchik A. V. F. M. Dostoevskiy - redaktor avtorskikh tekstov v ezhenedel'nike «Grazhdanin» (1873-1874). Novye razyskaniya i versii [Fyodor Dostoevsky as an Editor of Author Texts in the Weekly "Grazhdanin" (1873-1874). New Searches and Versions]. Baltika. Tallin, E'stonia, 2010, pp. 69-77.

18. Otlivanchik A. V. Neizvestnyy tekst Dostoevskogo? K voprosu ob avtorstve stat'i «Semeynaya neuryaditsa kak prichina samoubiystva» («Grazhdanin», 1873, № 49) [An Unknown Text of Dostoevsky? On the Authorship of the Article "Family Problem as 
a Cause of Suicide" (“Grazhdanin”, 1873, No 49)]. Dostoevskiy i sovremennost': materialy XXI Mezhdunarodnykh Starorusskikh chteniy 2006 g. [Dostoevsky and Modern Age: Proceedings of the 21st International Readings in Old Russian Culture, 2006]. Veliky Novgorod, 2007, pp. 217-233.

19. Tomashevskiy B. V. Dostoevskiy-redaktor [Dostoevsky as an Editor]. Dostoevskiy F. M. Polnoe sobranie sochineniy khudozhestvennykh proizvedeniy [Dostoevsky F. M. The Complete Works of Fiction]. Moscow, Saint-Petersburg, 1930, vol. 13, pp. 559-593.

20. Tunimanov V. A. Zavershenie mnogoletnego truda [The Result of Years of Work]. Russkaya literatura. 1976, no. 2, pp. 199-206. 